\title{
The West Gondwana margin: Proterozoic to Mesozoic
}

The longevity and extent of the oceanic southem margin of Gondwana have made it the subject of intense study for more than 70 years. It was one of the cradles of terrane theory and remains a proving ground for theories of supercontinent amalgamation and bre:ak-up. Investigation of processes on this margin, such as accretionary orogenesis and terrane analysis, is vital to our understanding of the Proterozoic and Phanerozoic evolution of the continental crust. In this special issue of Gondwana Research, entitled "The West Gondwana Margin: Proterozoic to Mesozoic", we have assembled 9 research papers addressing various aspects of the evolution of the West Gondwana margin, first presented at the intemational meeting 'Gondwana 12 (Geological and Biological Heritage of Gondwana)', held in Mendoza, Argentina, in November 2005. Many concem southem South America, which has a fairly continuous Proterozoic to Mesozoic geological record.

A Focus Paper by A.P.M. Vaughan and R.J. Pankhurst provides a "Tectonic overview of the West Gondwana margin". It provides an up-to-datc definition of West Gondwana based on the cratonic clements, the Mesoproterozoic and Neoproterozoic mobile belts, the Palaeozoic-Mesozoic terranes, and the boundary with East Gondwana. The history of formation and dispersal of the supercontinent is summarized, and each sector of the oceanic nargin receives a brief state-of-the-art review. Part of the discussion concentrates on the South American sector, where there are widely-debated hypotheses of collisional accretion involving pre-existing continental crustal terranes (the Precordillerch, Pampia and Chilenia terranes, and Patagonia). Voluminous silicic magmatic provinces characterise this part of the margin and abundant accretionary complexes form the outermost and youngest part. The geology of the South African sector is treated next, followed by West Antarctica, with the most up-to-date summary so far, including the most recent results from terrane studies of the Antarctic Peninsula. The final sections deal with New Zealand, Victoria Land and the Transantarctic Mountains - parts of the East Gondwana nuargin that acted as sinks for, or sources of, West Gondwana sedimentary material or terranes. The paper finishes with some observations on possible future directions for studies of the Gondwana margin.

The other contributions are ordered broadly in terms of the chronology of processes. The paper by C. Casquet, R.J. Pankhurst, C.W. Rapela, C. Galindo, C.M. l'anuing, M.
Chiaradia, E. Baldo, J.M. Gonzalez-Casado and J.A. Dahlquist on "The Maz terrane: a Mesoproterozoic domain in the westem Sierras Pampeanas, Argentina, equivalent to the ArequipaAntofalla block of southem Perú? Implications for West Gondwana margin evolution" sheds new light on the Middle and Late Proterozoic evolution of the westem Amazonia margin that preceded final amalgamation of West Gondwana in the Late Neoproterozoic Early Cambrian. The Maz terrane (Westem Sierras Pampeanas) is recognised as a new continental terrane that underwent Grenvillian-age orogeny and was thoroughly rejuvenated during the Ordovician Famatinian orogeny. Nd- and $\mathrm{Pb}$-isolope geochemistry allows correlation of Maz metasedimentary rocks with the Mesoproterozoic northem part of the Arequipa Antofalla craton, a region of pre-Andean basement in southem Perú. These were probably continuous along the palaeo-margin of the Amazonia craton, at least until the end of the Neoproterozoic.

The paper by A.B. Guereschi and R. D. Martino ("Field and textural evidence of two migmatization events in the Sierras de Córdoba, Argentina") focuses on tectonothermal evolution in the internal part of the Pampean orogen where mignuatites are widespreat. The authors introduce for the first time the pullpush concept for the Pampean orogen, i.e., a succession of compressional and extensional events, nirroring the tectonic processes of subduction and collision of the Pampia terrane against the West Gondwana margin. In contrast to former views of this being a short-lived Larly Cambrian orogeny, they suggest a long duration, starting some 30 to $50 \mathrm{Ma}$ earlier, in the Late Neoproterozoic.

The paper by C.J. Chemicoff, E.O. Zappettini, J.O.S. Santos, Beyer, E. and N.J. McNaughton on "Foreland basin deposits associated with Cuyania accretion in La Pampa province, Argentina" presents a multidisciplinary study of part of a large pre-Carboniferous marine basin in westem Argentina (the Curacó basin), whose depocentres are defined by aeromagnetic data. Field and petrological studies show that the scdimentary sequence in the easternmost depocentre, on Gondwana continental crust, can be divided into two distinct unconformable formations (Late Ordovician-Devonian and Permian, respectively). Scdimentary geochemistry of the lower sequence indicates an active margin depositional environment, and $\mathrm{U}-\mathrm{Pb}$ SHRIMP dating of detrital zircon confirms a Late Ordovician depositional age, with provenance from a Cambrian (Pampean) 
source. Hf isotope data on the zircons show that the source region was mature, but generally not as old as Palaeoproterozoic. The authors interpret this as a foreland basin resulting from Mid Ordovician collision of the Precordillera terrane (Cuyania), with sedimentation across the palaeo-suture.

The paper by J. L. Alonso, J. Gallastegui, J. GarciaSansegundo, P. Farias R. Rodríguez Femandez and V. A. Ramos on "Extensional tectonics and gravitational collapse in an Ordovician passive margin: the western Argentine Precordillera" describes ubiquitous extensional structures developed in Ordovician rocks in the Argentine Precordillera. These structures include normal faults and boudinaged sequences that illustrate a range of deformational styles developed while the sediments were still soft during the early stages of lithification. Structural data support the interpretation that gravitational collapse related to submarine sliding was the cause of extensional deformation. The new data support earlier conclusions locating an Ordovician continental slope between the ocean floor of the westernmost part of the Precordillera and the carbonate platform of the central Precordillera, interpreted as a passive continental margin.

The paper by B. Castro de Machuca, G. Arancibia, D. Morata, D. Belmar, L. Previley and S. Pontoriero on the " $P-T-t$ evolution of an Early Silurian medium-grade shear zone on the west side of the Famatinian magmatic arc, Argentina: implication for the assembly of the western Gondwana margin" investigates the duration of the Famatinian tectono-thermal event that supposedly resulted from collision of the Laurentiaderived Precordillera terrane. The authors chose a shear zone within basic igneous rocks belonging to the Famatinian magmatic arc and determined an Early Silurian ${ }^{40} \mathrm{Ar} /{ }^{39} \mathrm{Ar}$ age on amphibole, younger than Middle Ordovician peak-metamorphic ages obtained by other workers. Their interpretation is that this age represents cooling through late orogenic uplift and decompression of the Famatinian mobile belt. Determination of $P-T$ conditions reinforce the view than Famatinian peak metamorphism was at high- $T$ and intermediate- $P$.

S.E. Geuna, L.D. Escosteguy and R. Miró in their paper entitled "Palaeomagnetism of the Late Devonian-Early Carboniferous Achala Batholith, Córdoba, central Argentina: implications for the apparent polar wander path of Gondwana" argue for a mid-Palaeozoic age (380-360 Ma) for a palaeomagnetic pole derived from the Achala batholith, a major postorogenic complex emplaced in the metamorphic-plutonic basement of the Eastern Sierras Pampeanas. The body, consisting mainly of porphyritic to coarse-grained equigranular monzogranite, has a crystallization age of $\sim 370$ and a cooling age of $\sim 340 \mathrm{Ma}$; it is exposed as asymmetric, eastward-tilted blocks. The palaeomagnetic pole based on 43 sites is located at $56^{\circ} \mathrm{S}, 307^{\circ} \mathrm{E}$ and fits a complex mid-Palaeozoic apparent polar wander path ("Y-type") for Gondwana, which may involve rapid movement, true polar wander episodes and/or continental collisions before the final amalgamation of Pangea.

The paper by F.A. Sepúlveda, F.Hervé, M. Calderón and J. P. Lacassie on "Petrology of metamorphic and igneous units from the allochthonous Madre de Dios Terrane, Magallanes, Chile" describes metamorphosed pillow basalts, metahyaloclastites, banded metalliferous and radiolarian metacherts, metapelites and redeposited calcareous metasandstones of the Denaro complex, part of the Madre de Dios terrane. The basaltic rocks plot in the N-and E-type MORB fields of tectonic discriminant diagrams and were probably erupted along a constructive plate margin. They possess a foliation interpreted as having developed during accretion of the terrane to the Gondwana margin. The authors argue that the structural and metamorphic data (pumpellyite-actinolite facies) suggest formation in an accretionary wedge at relatively low $T$ and $P$, probably during the Late Triassic-Early Jurassic Chonide event.

C. Adams ("Geochronology of Palaeozoic terranes at the Pacific Ocean margin of Zealandia") presents new geochronological data from the largely submerged part of East Gondwana of which New Zealand is the largest emergent part. This includes Lord Howe Rise, Challenger Plateau, the New Zealand mainland itself, Chatham Rise and Campbell Plateau. The new data suggest that that the Campbell Plateau is mostly underlain by Early Palaeozoic metasediments intruded by (1) Early to mid-Cretaceous granitoids along the western margin, extending north to New Zealand and south to Antarctica, and (2) Early Jurassic granitoids of Bounty Platform, extending to Marie Byrd Land.

The final paper is by D.H. Elliot and C.M. Fanning: "Detrital zircons from Upper Permian and Lower Triassic Victoria Group sandstones, Shackleton Glacier region, Antarctica: evidence for multiple sources along the Gondwana plate margin". This presents new SHRIMP zircon data showing that the Victoria Group sediments had a contemporaneous Late Permian magmatic source, with subsidiary Neoproterozoic, Devonian and Cambrian sources. Palaeocurrent flow directions indicate derivation of the Permian detritus from the West Antarctic flank of the Beacon foreland basin, the inferred Panthallassan plate margin. The Devonian source is attributed to the Ford granodiorite suite in Marie Byrd Land, West Antarctica. Because the Beacon basin strata cover the Cambrian Ross orogen and extend onto older basement, the Cambrian and Upper Proterozoic zircons are interpreted as reworked from Devonian and/or Lower Permian Beacon sandstones exposed as a result of the onset of folding and thrusting in Late Permian time.

In assembling this special issue of Gondwana Research, we acknowledge the major contribution made by the authors in submitting their manuscripts and undertaking important revisions where necessary. We are all indebted to the following for generously giving their time in order to provide scholarly and painstaking reviews: J. Abati, J. Arribas, H. Bahlburg, E.G. Baldo, L. Barbero, M.A. Basei, J.D. Bradshaw, J.M. Cebria, M.J. Curtis, M. Flowerdew, J.D. Gleason, P. Gonzalez, D. Gregori, L.P. Gromet, F. Hervé, J.P. Hibbard, J.L. Isbell, R.J. Korsch, P.T. Leat, Jiabiao Li, E.J. Llambías, M. López de Luchi, Xiwu Luan, H.-J. Massonne, I. Metcalfe, C. Mpodozis, M. Palin, S.H. Peralta, O. Rabbia, A.E. Rapalini, J. Schwartz, L.A. Spalletti, R.A.J. Trouw, C.R. Van Staal, R. Varela, W. von Gosen, G. Vujovich, A. Wandres, N. Woodcock, Nengyou Wu, U. Zimmermann. We thank Gondwana Research for support in publishing this special issue and hope that the papers assembled herein will contribute to 
state-of-the-art knowledge and promote continued research resulting in a deepening understandings of the Gondwana margin in the future.

\section{Casquet}

Gniversidad Complutense. Spain

Comesponding ituthor.

Tel.: $+34913944908:$ tax: -34915442535 .

E-mail address: casquetóageo.wen.cs.

\section{R.J. Pankhurst}

Brifish Geological Sureg? LK F-mail atdlress: riptaniglnetcac.uk.

A.P.MI. Vaughim

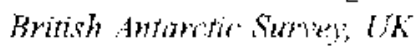

E-mail address: a.vaughan $\bar{a}$ bas.ac.uk. 